\title{
Spanien: Når ideologi og identitet flyder sammen
}

Af Jørgen Laurvig

De catalanske nationalisters kamp for løsrivelse fra Spanien har domineret spansk politik de seneste år. Med en afsat selvstyrepræsident på flugt $i$ Tyskland og andre toppolitikere $i$ fængsel kan separatisterne ikke bruge deres flertal i det regionale parlament til noget. Og regeringen i Madrid kan ikke i længden leve med, at et af landets økonomiske kraftcentre er paralyseret politisk.

Et politisk spørgsmål besvares med jura. Separatistiske politikere taler på et ikke-eksisterende flertals vegne, mens den nationale regering taler om en nation, der ikke eksisterer i befolkningens bevidsthed. Historiebøger skrives om, tonen skærpes til et leje mellem hadsk og fordomsfuld, og grøftegraverne har kronede dage.

Situationen i Catalonien er fastlåst: De tre catalanske separatistpartier har vundet flertal i selvstyreparlamentet ved flere valg, og gennemførte den
1. oktober 2017 en folkeafstemning om løsrivelse fra Spanien. Både den spanske forfatningsdomstol og den catalanske højesteret erklærede afstemningen forfatningsstridig og dermed ulovlig af gennemføre.

Afstemningsdagen blev præget af blodige sammenstød mellem demonstranter og politistyrker.

Den 27. oktober udråbte separatisterne en selvstændig republik, hvilket fik den spanske regering til at afsætte selvstyreregeringen og iværksætte forfatningens artikel 155, så Madrid-regeringen direkte styrer Catalonien.

Vicepræsident Oriol Junqueras, flere ministre og en række organisationsledere blev arresteret, mens den tidligere selvstyrepræsident Carles Puigdemont og fem andre ministre flygtede til Bruxelles. Siden har Puigdemont besøgt blandt andet Danmark for at tale løsrivelsesbevægelsens sag. Men den 25. marts klappede fælden i Tyskland, og i skrivende stund venter

Jørgen Laurvig er freelance-journalist og følger Spanien for P1 Orientering på DR. Han er tidligere reporter på DR's TV Avisen, Horisont og Radioavisen og har fulgt spansk politik tæt siden midten af 1980'erne, hvor han Iæste på Sevillas Universitet. Artiklen er skrevet før premierminister Mariano Rajoy den 1. juni blev fældet af et mistillidsvotum i det spanske underhus, og Pedro Sanchez fra det socialistiske arbejderparti, PSOE, overtog posten. 
Puigdemont på, at en tysk domstol afgør, om han kan udleveres til retsforfølgelse i Spanien.

I Madrid nægter den konservative regering fortsat, at separatisterne har et legitimt politisk krav på en forhandling om Cataloniens fremtid. For de konservative er det idéen om Spanien, tanken om en nation, der er på spil. Så følelser vinder over argumenter på begge sider af pigtrådshegnet, der skiller de to modparter.

\section{En nationalismes fødsel}

Kernen i den catalanske nationalisme er sproget, der er ét af mange latinske sprog på den Iberiske Halvø. I middelalderen var der tre dominerende magter på halvøen: De muslimske herskere i syd, Castilien i det centrale og nordlige Spanien og Aragonien i det nordøstlige, og i 1137 sluttede fyrstedømmet Catalonien sig til Aragonien. en vis selvstændighed. Catalanerne stifter deres første forsamling, der senere danner grundlaget for det catalanske selvstyreparlament.

Da den spanske kong Carlos II døde barnløs i 1701, udbrød en arvefølgekrig mellem prins Felipe fra huset Bourbon i Frankrig og den østrigske kejsers bror, ærkehertug Karl, fra den habsburgske slægt. Briterne og hollænderne ville ikke acceptere en alliance mellem Frankrig og Spanien, så de støttede den østrigske side i krigen, der blandt andet kostede Spanien herredømmet over Gibraltar. Men Felipe og bourbonerne fik overtaget i krigen, og den 11. september 1714 faldt Barcelona. Derfor er den 11. september blevet Cataloniens nationaldag. Bourbonernes sejr i arvefølgekrigen førte til en stærkt centraliseret statsdannelse, hvor catalanerne mistede væsentlige dele af deres autonomi.

Under romantikken redefinerede baskiske og catalanske intellektuelle deres mindretals identiteter og skabte en forestilling om regionerne som egentlige nationer. De regionale nationalismer fik yderligere næring, da det spanske imperium

I 1469 giftede Fernando af Aragonien sig med Isabel af Castilien, og i 1492 erobrede 'de katolske monarker' det sidste muslimske kongedømme i Granada. Spanien var samlet. Samme år 'opdagede' Columbus Amerika på vegne af dronning Isabel, og mens kongeparret var optaget af de nye kolonier, nød de spanske fyrstedømmer kollapsede i 1898 med tabet af Cuba, Puerto Rico, Guam og Filippinerne til USA.

Efter diktatoren Primo de Riveras fald og kong Alfonso XIII's eksil fra Spanien bliver den anden republik udråbt i 1931. I Catalonien udråber det republikanske socialdemokratiske parti Esquerra Republicana de Cata- 
nunya, ERC, Catalonien som en selvstændig republik inden for en føderation. Men uafhængigheden varer kun tre dage, før republikken igen samles under én regering.

I 1936 bryder den spanske borgerkrig ud med fascisten Francos oprør. Fascisterne indtager Barcelona den 26. januar 1939, Madrid falder den 27. marts, og den 28. marts flygter den sidste republikanske regering fra Alicante. Den 1. april 1939 erklærer Franco total sejr. Alligevel hersker forestillingen om, at Catalonien var republikanernes højborg, der holdt længst ud mod fascisterne, blandt catalanerne. Blandt mange catalanere er den catalanske nationalisme pr. definition anti-fascistisk - og som en konsekvens af denne logik kan man ikke støtte Spaniens nationale enhed og samtidig være anti-fascist, venstreorienteret eller demokrat.

\section{Den moderne nationalisme}

Som et led i undertrykkelsen forbød Franco brugen af baskisk, galicisk, aragonsk, valenciansk, balearisk og catalansk i det offentlige rum. End ikke castilianske dialekter optrådte i det offentlige rum.

I 1975 døde diktator Francisco Franco, og i 1978 fik Spanien en ny forfatning, der gav udstrakt selvstyre til de 17 autonome regioner. Den catalanske nationalist Jordi Pujol gik i spidsen for den borgerlige koalition CiU - Convergencia i Uniò - og var selvstyrepræsident fra 1980-2003.

Pujol udnyttede behændigt sit partis position som støtteparti for skiftende spanske regeringer til at sikre Catalonien mere selvstyre end mange andre regioner. Pujol nedsatte et udvalg af catalanske politikere, akademikere, journalister og kunstnere, der skulle styrke den catalanske nationalisme. Catalansk er nu officielt sprog i Catalonien, hvor man ikke kan få offentlig ansættelse uden at tale og skrive catalansk, og i uddannelsessystemet bliver der primært undervist på catalansk. Alligevel kan omkring halvdelen af indbyggerne i Catalonien hverken læse eller skrive catalansk på et niveau, der giver adgang til at søge offentlig ansættelse. For en stor del af befolkningen er tilflyttere fra andre regioner.

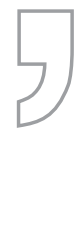

\section{Blandt mange catalanere er den catalanske nationalisme pr. definition anti-fascistisk - og som en konsekvens af denne logik kan man ikke støtte Spaniens natio- nale enhed og samtidig være anti-fascist, venstreorienteret eller demokrat.}

I skolerne undervises i en historie skrevet af catalanske nationalister, hvor centralstyret i Spanien bliver fremstillet som en fjende af catalanerne. Så når man er blandt yngre catalanere, vil man ofte høre påstande som: 'catalanerne er mere europæere end spanierne', 'tyrefægtning er barbari og typisk for spanierne', 'andaluserne er dovne og betaler ikke skat', 'madrilenerne er fascister'.

\section{Fra nationalisme til separatisme}

I 2006 var omkring ti pct. af catalanerne tilhængere af løsrivelse. De catalanske politikere (under ledelse af den 
regionale afdeling af de spanske socialdemokrater i PSC, der ikke støtter løsrivelse) havde dette år forhandlet en ny selvstyreaftale med den daværende socialdemokratiske regering i Madrid. Den skulle sikre Catalonien samme økonomiske udligningsforhold som Baskerlandet, der har større selvstyre end Catalonien.
I mellemtiden var det borgerlige CiU igen kommet til magten og var i skudlinjen for sin håndtering af den $ø$ konomiske krise. Selvstyrepræsident Artur Mas forsøgte at presse den konservative regering i Madrid til indrømmelser, men premierminister Mariano Rajoy var mere optaget af at leve op til EU's sparekrav end at tækkes de catalanske politikere. Mariano Rajoys stædighed som forsvarer af nationens enhed - han var partileder, da selvstyreaftalen blev indbragt for forfatningsdomstolen - gjorde ham

Det faldt det nationalkonservative folkeparti Partido Popular så meget for brystet, at partiet indbragte selvstyreaftalen for den spanske forfatningsdomstol. Det konservative parti var ikke kun modstander af de forbedrede økonomiske udligningsvilkår, men også af selvstyreaftalens anerkendelse af Catalonien som en nation og fortrinsretten til det catalanske sprog. Ifølge de nationalkonservative er Spanien 'et, stort og udeleligt', en katolsk nation defineret af de 'katolske monarkers' samling af magten og erobringen af det sidste muslimske kongedømme i 1492.

Den 28. juni 2010 afgjorde forfatningsdomstolen, at selvstyreaftalen var i strid med forfatningen. I ugerne efter bredte demonstrationerne sig som en bølge over Catalonien under slagordet ' $\mathrm{Vi}$ er en nation, vi har ret til at bestemme'. Nationaldagen 11. september blev et tilløbsstykke uden fortilfælde, og det gentog sig i 2011. til den perfekte fjende for separatisterne. Så i 2012 sluttede Artur Mas sig til separatisterne. Et perfekt røgslør for det politiske ansvar, der hviler over hans partis forvaltning af Catalonien, som CiU har regeret 1980-2003 og igen siden 2006.

Den økonomiske politik har gjort Catalonien til den næstmest forgældede region i Spanien (efter Valencia), og nedskæringerne i det offentlige uddannelses- og sundhedssystem har været dramatiske. Nu kunne Artur Mas sende aben videre til Madrid. Forestillingen om, at Catalonien betaler for resten af Spanien, blev rendyrket. Regionen bidrager i totale tal mest til det spanske BNP, men hvis man taler om BNP pr. indbygger, er det hovedstadsregionen Madrid, Baskerlandet og regionen Navarra, der bidrager mest til statskassen.

Efterhånden var der over 45 pct. af catalanerne, der støttede løsrivelse og Mas satte i 2014 en vejledende fol- 
keafstemning i gang. Deltagelsen var lav, ikke-separatisterne blev hjemme. Men separatisterne følte, de havde fået et folkeligt mandat til at forhandle en bindende folkeafstemning. Det nægtede Mariano Rajoy, og derfor gjorde Artur Mas regionalvalget den 27. september 2015 til en folkeafstemning for eller imod løsrivelse: hvis man var separatist, skulle man stemme på ét af de tre løsrivelsespartier. Det nationalkonservative CiU slog sig sammen med det socialistiske Esquerra Republicana i valgforbundet Junts Pel Si ('Sammen for et ja') for at bane vejen for en bindende folkeafstemning.

\section{Åben konflikt med Madrid}

Separatisterne fik flertal i det nyvalgte parlament - men kun i kraft af ti mandater fra det yderste venstre i det anti-kapitalistiske valgforbund CUP, samt i kraft af dette spanske valgsystem, der styrker store partier i de enkelte valgkredse, og i Catalonien har man tilmed favoriseret tyndt befolkede landområder i fordelingen af mandater.

Så med 47,8 pct. af stemmerne ( $\bmod$ oppositionens 48,09 pct.) fik separatisterne flertal i parlamentet. CUP tog sig imidlertid dyrt betalt for støtten: venstrefløjen mente, at Artur Mas var korrupt og indblandet $i$ en meget omfattende korruptionsskandale med 'landsfader' Jordi Pujol og hans familie som centrum. Så efter måneders tovtrækkeri trak Artur Mas sig, og den indtil da relativt ukendte Carles Puigdemont blev selvstyrepræsident.

Samtidig begyndte det catalanske selvstyre at åbne 'ambassader' i en række europæiske lande, hvor ngo'en Asamblea Nacional Catalana havde lobbyet for løsrivelse i flere år. Blandt andet i Danmark, hvor Enhedslisten har promoveret den catalanske løsrivelse, blandt andet med forespørgselsdebat i Folketinget den 19. maj 2015.

Strategien var at skabe europæisk støtte til det 'undertrykte catalanske folks legitime krav på at udfolde sig demokratisk og selvstændigt'.

De catalanske separatister tegnede et billede af en selvstændig republik som et demokratisk, velstående velfærdssamfund efter skandinavisk forbillede. 'Danmark ved Middelhavet' blev et slagord.

Carles Puigdemont udskrev en folkeafstemning til den 1 . oktober 2017. Men både den spanske forfatningsdomstol og den catalanske højesteret erklærede folkeafstemningen for forfatningsstridig.

Den spanske anklagemyndighed gjorde det klart, at de ansvarlige for en eventuel folkeafstemning ville blive retsforfulgt.

Da den ulovlige afstemning gik i gang i et regnvådt og køligt Catalonien den 1 . oktober, undlod det regionale politi at gribe ind. På lang de fleste valgsteder forløb afstemningen uden episoder.

Men for eksempel på Ramon Llull-skolen i Barcelona blev det nationale politi sat ind for at beslaglægge urner og stemmesedler. Først måtte politifolkene med magt fjerne catalanere i alle aldre fra skolens trapper, før de kom ind i bygningen. Da politiet forsøgte at køre fra skolen, blev de blokeret af flere hundrede mennesker, 
der havde sat sig ned for at spærre de snævre gader. Efter en nervekrig på næsten 45 minutter trak politiet kniplerne for at komme ud. Demonstranterne svarede igen med kasteskyts, og politiet affyrede gummikugler. En mand faldt blødende om - en gummikugle havde ramt ham i øjet.

De voldsomme billeder gik kloden rundt med fortællinger om politiets brutalitet.

\section{Opløsning af parlamentet}

Ni ud af ti vælgere stemte for løsrivelse - men valgdeltagelsen var kun 43 pct., og iagttagere var enige om, at stort set kun separatister var mødt op for at deltage i den ulovlige afstemning. Ved det seneste valg i Catalonien var valgdeltagelsen 79 pct.

\section{Nu tikker det forfatningsmæssige ur, så hvis ikke flertallet i det catalanske parlament udpeger en regering senest den 23. maj, bliver der automatisk udskrevet valg.}

Antikapitalisterne i CUP pressede på for, at Puigdemont skulle erklære løsrivelse og udråbe en selvstændig republik. En ny nervekrig begyndte; Puigdemont mødte modstand i egne rækker. Men den 27. oktober bøjede han sig for presset, og erklærede Catalonien uafhængigt af Spanien.

Svaret fra Madrid kom prompte. Forfatningens artikel 155 blev iværksat, selvstyreparlamentet opløst, og der blev udskrevet valg. Den afsatte regering blev tiltalt for opfordring til voldeligt oprør og misbrug af offent- lige midler - anklagemyndigheden mener, at separatisterne har brugt offentlige midler til deres kampagne. Hundredtusinder demonstrerede i gaderne mod Madrids indgriben - men andre hundredtusinder gik på gaden for at forsvare Spaniens enhed. Det stod klart, at befolkningen er delt i to nærmest lige store lejre, hvor ingen af siderne har flertal.

Premierminister Mariano Rajoy satsede på, at separatisterne ville miste flertallet ved et valg - han opfordrede flere gange de catalanske vælgere og politikere til 'at komme til fornuft'. Men det viste sig at være en virkelighedsfjern strategi. Rajoys konservative parti $\mathrm{PP}$ er så gennemsyret af korruptionsskandaler, at valget blev en katastrofe for premierministeren. PP gik fra 11 til fire mandater, mens det nye borgerlige parti, Ciudadanos, vandt 11 mandater og blev det største parti i Catalonien med 36 mandater. Men separatisterne bevarede flertallet, nu med en opbakning på 47,49 pct.

Meget tyder på, at enigheden mellem de to store separatistpartier om strategi og politik knager voldsomt i fugerne, og kun antikapitalisterne $\mathrm{i}$ CUP står fast på løsrivelseserklæringen.

I første omgang har separatisterne forsøgt at genindsætte Carles Puigdemont som præsident, endda via videokonference. Men det har juristerne i det catalanske parlament sagt nej til. Næste kandidat på listen har været Jordi Sánchez, der leder den store ngo Asamblea Nacional Catalana. Men 
han sidder fængslet, sigtet for vold i forbindelse med en demonstration, der udviklede sig til hærværk.

$\mathrm{Nu}$ tikker det forfatningsmæssige ur, så hvis ikke flertallet i det catalanske parlament udpeger en regering senest den 23. maj, bliver der automatisk udskrevet valg.

Dele af separatisterne satser stadig på, at EU skal gribe ind og presse den spanske regering til forhandlingsbordet. Men det er ønsketænkning. EU vil ikke støtte catalanerne, fordi hverken Tyskland, Frankrig eller Italien er interesseret $i$ at sætte en lavine af regionale selvstændighedskrav i gang. Rajoy vil ikke forhandle med separatisterne, så der skal en ny regering til magten i Madrid, før en forhandling bliver mulig.

Socialdemokraterne og det borgerlige Ciudadanos har luftet tanken om en ny spansk forfatning, der gør Spanien til en føderal stat. Det kunne måske tage brodden af den moderate del af separatisterne, især hvis der følger penge med. Men det næste valg i Spanien skal ikke afholdes før senest i 2020, og da det korrupte konservative regeringsparti står til en mega-vælgerlussing, har Rajoy ingen grund til at udskrive valg før tid.

Den catalanske hårdknude går kun strammere tider i møde inden for en overskuelig fremtid.

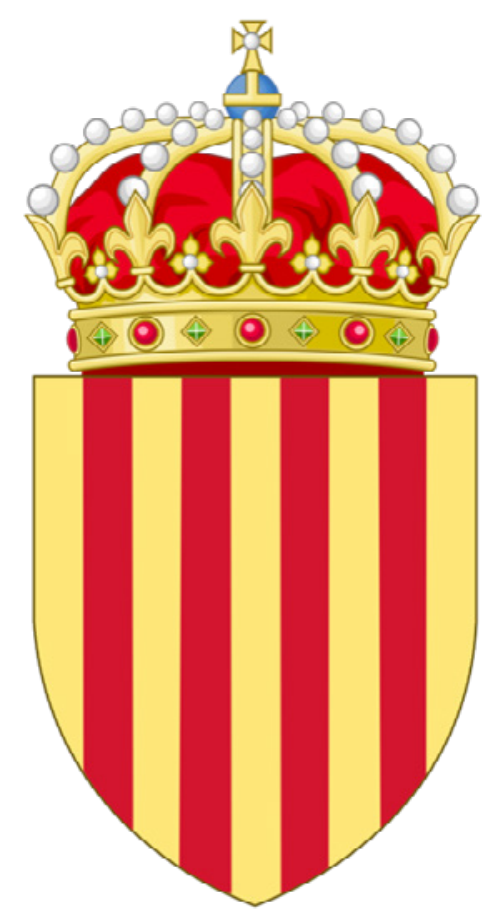

ILL.: Valadrem, SMP \& Vilallonga via Wikimedia Commons

Cataloniens våbenskjold 